Przegląd Prawa Konstytucyjnego

--ISSN 2082-1212--------

DOI 10.15804/ppk.2017.04.05

$-\mathrm{Nr} 4(38) / 2017$

Thomas Würtenberger ${ }^{1}$

Jan Wiktor Tkaczyński

\title{
Nowe instrumenty postępowania administracyjnego w Niemczech? Między akceptacją a mediacją
}

Słowa kluczowe: niemieckie prawo administracyjne i konstytucyjne Keywords: german public and administrative law

\section{Streszczenie}

Trudno nie przyznać, że rozwój współczesnego społeczeństwa pociąga (a przynajmniej pociągać za sobą powinien) również zmiany w funkcjonowaniu państwa. Ta banalna raczej jak naukowe odkrycie konstatacja ma jednak daleko idące konsekwencje dla (z)rozumienia w dzisiejszych czasach roli demokratycznego państwa prawa. Nie da się bowiem przeoczyć, że od czasów Rewolucji Francuskiej państwo jest poddawane nieustannie przeobrażeniom, których w tak głębokiej skali nie poznały ubiegłe stulecia. Pomijając rozważania nad kierunkiem rozwoju współczesnej państwowości, warto - mówiąc właśnie o ustrojowych zmianach - mieć stale przed oczyma to, co składa się na administracyjną tożsamość państwa w jego relacjach z obywatelem. Jak jest ona w przedmiotowym aspekcie kształtowana i jak wreszcie uzupełnianie demokracji reprezentatywnej o elementy partycypacji i responsywności obywatelskiej ma miejsce. Po to, aby łatwiej i szybciej, a nade wszystko skuteczniej móc reagować na nowe zagrożenia i zarazem wyzwania cywilizacyjne. Tych bowiem, jak wszystko na to wskazuje, nie zabraknie też w nadchodzących latach.

1 Autor jest profesorem na Wydziale Prawa Uniwersytetu Albert-Ludwigs we Freiburgu. E-mail: Thomas.Wuertenbergeratjura.uni - freiburg.de.

2 Autor jest profesorem w Instytucie Europeistyki Wydziału Studiów Międzynarodowych i Politycznych Uniwersytetu Jagielloński w Krakowei. E-mail: jan.tkaczynski@wp.pl. 


\section{Summary}

\section{New instruments of administrative procedure in Germany? Between acceptance and mediation}

It is hard not to admit that, the development of contemporary society results (or at least it shall result) in changes of state's functioning. This trival statement, as for scientific discovery, has far - reaching implications for understanding in contemporary world the position of democratic state based on the rule of law. It is impossible not to see that since the French Revolution the state is under sustained transformations, which in such a deep scale were not observed in previous centuries. Without going into considerations on the modern statehood course, it is worth - when focus on institutional changes - bear in mind what consists of state's administrative identity in relation with it's citizens. In this context - how it is shaped and how take place the fulfilment of representative democracy with elements such as citizen's participation and responsiveness. For easier, faster, and the most important - more effective, way of reaction on new threats and civilization challenges. Which - without any doubts there will be no lack of abovementioned ones in forthcoming years.

Trudno nie przyznać, że rozwój współczesnego społeczeństwa pociąga (a przynajmniej pociągać za sobą powinien) również zmiany w funkcjonowaniu państwa. Ta banalna raczej jak naukowe odkrycie konstatacja ma jednak daleko idące konsekwencje dla (z)rozumienia w dzisiejszych czasach roli demokratycznego państwa prawa. Nie da się bowiem przeoczyć, że od czasów Rewolucji Francuskiej, kiedy państwo zaczęło przechodzić we władanie wszystkich obywateli, mądrych i głupich, słabych i silnych, bogatych i biednych wreszcie, jest ono poddawane nieustannie przeobrażeniom, których w tak głębokiej skali nie poznały ubiegłe stulecia. Nie wdając się tutaj w rozważania nad kierunkiem rozwoju współczesnej państwowości, warto jednak mieć - mówiąc właśnie o ustrojowych zmianach - stale przed oczyma to, co składa się $\mathrm{w}$ relacjach państwa $\mathrm{z}$ obywatelem na jego administracyjną tożsamość. Jak jest ona w przedmiotowym aspekcie kształtowana i jak wreszcie uzupełnianie demokracji reprezentatywnej o elementy partycypacji i responsywności 
obywatelskiej ma miejsce. Po to, aby łatwiej i szybciej, a nade wszystko skuteczniej móc reagować na nowe zagrożenia i zarazem wyzwania cywilizacyjne. Tych bowiem, jak wszystko na to wskazuje, nie zabraknie też w nadchodzących latach.

\section{Artykulacja zasady pluralizmu w procesie tworzenia prawa}

Niezależnie od normatywnego sposobu uregulowania zasady pluralizmu, trudno nie zgodzić się z tezą, iż pluralizm pozostaje nadal kluczowym elementem życia politycznego, i to zarówno na poziomie narodowym, jak i supranarodowym. Począwszy od XIX w. jest on bowiem obiektem nie tylko permanentnej dyskusji, ale i tworzywem ustrojowego eksperymentowania. To ostatnie daje się dobrze zilustrować na przykładzie procesu parlamentarnego stanowienia prawa według trzech modeli pozwalających na wgląd w możliwości rozwiązywania problemu udziału w nim (różnie definiowanych) grup społecznych interesów. Patrząc zatem od tej strony możemy uznać za:

typowy model współdecydowania i współkształtowania treści ustaw taki udział w pracy organu stanowiącego prawo (parlamentu), jaki wynika z faktu, że gremia społeczne (rady, komisje, komitety) są najczęściej organami powołanymi na mocy konstytucji lub ustaw, a ich ideą jest przedstawianie interesów społecznych w sposób wyważony, a zatem - według idealnego założenia - reprezentatywnie. I to pomimo, że ich członkowie nie mogą się w przeciwieństwie do posłów do parlamentu - powołać na legitymację pochodzącą z wyboru.

Pewną modyfikację tak zorganizowanego negocjowania kształtu planowanego aktu prawnego stanowi zawarcie między stronami - kontrahentami porozumienia o charakterze konsensusu ${ }^{3}$. W tym przypadku mowa jest o (samo)zobowiązaniu, które dochodzi do skutku w wyniku porozumienia między stronami reprezentującymi interes publiczny z jednej a interes prywatny z drugiej. Warto tutaj, niejako na marginesie, dodać, że tego rodzaju porozumienia konsensualne zobowiązują w równym stopniu tak

3 P. M. Huber, Konsensvereinbarungen und Gesetzgebung, „Zeitschrift für Gesetzgebung", 2002, nr 3, s. 245-255. 
stronę publiczną jak prywatną do osiągnięcia określonego celu politycznego, jednakże bez odwoływania się do właściwych w tym względzie prawnych uregulowań bądź procedur. Gdyby zatem chcieć krótko zdefiniować ten rodzaj porozumienia (kompromisu) społecznego, to można by je określić mianem elastycznego instrumentu w tych obszarach, w których państwu (stronie publicznej) z dużą trudnością przychodzi sterowanie za pomocą prawodawstwa. Tym niemniej, i ten fakt należy również zachować w pamięci, wszystkie gremia reprezentujące określone interesy społeczne są zawsze gotowe do kompromisu dopiero wtedy, gdy obawiają się bardziej niekorzystnego uregulowania ustawowego aniżeli właśnie skutków rzeczonego porozumienia.

Model wysłuchania (hearing) pozwala na włączenie grup interesów społecznych bezpośrednio w sam proces ustawodawczy. W ramach tego procesu mogą w nim brać udział nie tylko wspomniane grupy, ale i eksperci. I, co równie ważne, już w trakcie przygotowywania przez rząd projektu danego aktu prawnego. Opisane oddziaływanie jest jednak oddzielone, musimy i to zauważyć, od lobbingu bardzo cienkim przepierzeniem.

Założenie funkcjonowania praworządnie rozumianej kultury administracyjnej w demokracji parlamentarnej jest znane: administracja realizuje uchwalone przez parlament ustawy w sposób fachowy i z neutralnym dystansem do różnych sił społecznych. Przy tym jej działanie jest legitymizowane przez demokratycznie wybrany parlament i zarazem ograniczone zasadami państwa prawa. W tak zakreślonych ramach przysługuje obywatelowi (grupie reprezentującej dany interes społeczny) w przypadku postępowania administracyjnego przywołane modelowo prawo albo do współudziału, albo do wysłuchania. Wszystko po to, aby - tak znowu idealne założenie w teorii - mogło mieć miejsce ulepszenie podstawy wydania decyzji administracyjnej i tym samym jej optymalizacja.

\section{W stronę nowej orientacji działania w postępowaniu administracyjnym}

Zarówno planowanie przestrzenne jak i postępowanie administracyjne, w których zachodzi potrzeba wyważenia (różnych) interesów, daje administracji co zresztą łatwo przewidzieć - wcale pokaźny margines swobody kształto- 
wania decyzji będącej ich wynikiem ${ }^{4}$. Regułą jest przy tym to, że im mniej realizacja określonej kwestii przestaje być prostym odzwierciedleniem woli ustawodawcy i zarazem im więcej pozostaje do rozwiązania sprzecznych interesów z nią związanych, to tym bardziej potrzebne jest właśnie opanowanie sztuki osiągania akceptacji podjętej decyzji. Jest to zrozumiałe, jeśli uwzględnić, że w przypadku, gdy porządek prawny nie określa w sposób jasny wzorców postępowania administracyjnego, to na plan pierwszy musi się wysunąć praktykowanie demokracji w jej partycypatywnej odsłonie. Stąd nie zaskakuje, że akceptacja jest tutaj i celem postępowania administracyjnego, i zarazem jego rezultatem.

Przedstawione rozwiązanie niesie atoli z sobą określone konsekwencje. W postępowaniu administracyjnym jest bowiem możliwe wniesienie sprawy zarówno przez władze jak i ze strony tych wnioskodawców, którzy reprezentują określony interes grupowy (społeczny). Inaczej mówiąc, mamy do czynienia w przedmiotowym postępowaniu administracyjnym z tzw. otwartością na strony konfliktu (Konfliktoffenheit des Verwaltungsverfahrens) ${ }^{5}$. Tym samym zadaniem jest tutaj poszukiwanie kompromisu, który je zadowoli. Zrozumiałe jest zarazem sformułowanie oczekiwania pod adresem administracji, iż umożliwi ona w ramach tego postępowania nie tylko wyczerpującą i rzeczową wymianę poglądów, czy też włączenie doń zewnętrznych ekspertów, ale i że oprze się naciskom, jak i że dopuści do otwartej (publicznej) dyskusji.

Oczekiwanie to, jak łatwo zgadnąć, zakłada taki sposób procedowania, jaki będzie odzwierciedlał możliwą do zaakceptowania decyzję w przewidzianych prawem ramach rzeczonego postępowania. Czy oczekiwanie to jest (w ogóle) możliwe do spełnienia, zależy w znacznym stopniu od urzędowego podejścia w każdym z przedmiotowych przypadków. Niewątpliwe jednak pozostaje to, że poszukiwany jest tu mediator, w którego bezstronności pokładają swoją

4 To typowe i tradycyjne dla administracyjnej praktyki niemieckiej stanowisko bierze swój początek z dwóch kryteriów, a mianowicie z zakresu swobodnej oceny (Beurteilungsspielraum) oraz uznania (Ermessen). Więcej na ten temat: E. Pache, Tatbestandliche Abwägung und Beurteilungsspielraum. Zur Einheitlichkeit administrativer Entscheidungsfreiräume und zu deren Konsequenzen im verwaltungsgerichtlichen Verfahren - Versuch einer Modernisierung, Tübingen 2001, s. 11, 20, 33, 57, 120.

5 I. Appel, Frühe Bürgerbeteiligung und Vorhabenakzeptanz, [w:] Verfassungsstaatlichkeit im Wandel. Festschrift für Thomas Würtenberger, red. D. Heckmann, R. P. Schenke, G. Sydow, Berlin 2013, s. 341, 343. 
ufność wszystkie strony konfliktu, ale i który potrafi równocześnie zadbać o zrozumiały i transparentny przebieg danego postępowania.

Nic tego tak dobrze nie dokumentuje jak konieczność wcześniejszego (a więc przed podjęciem decyzji) włączania w proces podejmowania decyzji administracyjnej tzw. czynnika społecznego. Zastanawia przy tym, że ta - z dzisiejszego punktu widzenia - ustrojowa oczywistość, torowała sobie w niemieckiej rzeczywistości administracyjnej drogę przez całe lata ${ }^{6}$. Dopiero po wielokrotnym, niejednokrotnie agresywnym przebiegu konfliktów wokół planowanych realizacji różnych projektów, zdecydowano się na istotną zmianę uregulowania $\$ 25$ ust. 3 zdanie 2 i 3 Ustawy o postępowaniu administracyjnym (Verwaltungsverfahrensgesetz, $\mathrm{VwVfG}$ ). Według nowej redakcji tego paragrafu, administracja jest zobowiązana do wskazania wnioskodawcy planowanej inwestycji na konieczność jej wcześniejszego przedstawienia opinii publicznej. Ten podwójny obowiązek, ciążący i na administracji, i na potencjalnym inwestorze, nie zawiera jednak w sobie dyspozycji ustawodawcy, jak ma koniec końców wyglądać ten wcześniejszy udział społeczny (frühe Öffentlichkeitsbeteiligung), bądź w jaki sposób zainteresowana strona społeczna może się wypowiedzieć (Gelegenheit zur Äußerung und zur Erörterung).

Pomimo tego raczej połowicznego sukcesu ustawowego, jedno nie ulega wątpliwości: zadaniem administracji jest i pozostaje wszczęcie procedury mającej na celu włączenie czynnika społecznego w przebieg podejmowania danej decyzji. Nie jest to - podkreślmy - zadanie o charakterze fakultatywnym, ale obligatoryjnym. Stąd administracja ma obowiązek sama, bądź (co lepiej) wespół z wnioskodawcą, przedstawić opinii publicznej wszystkie możliwe skutki związane z podjęciem określonej inwestycji. Postanowienie tego rodzaju oznacza zarazem możliwość zastosowania spektrum środków służących zapewnieniu dostępu do informacji, wykorzystaniu modeli symulacyjnych, przeprowadzeniu analizy korzyści i strat, a wreszcie zapewnieniu ewentualnej kompensacji. Wszystko po to, aby możliwie najwcześniej odkryć (zlokalizować) potencjalne przeszkody stojące na drodze realizacji planowanego przedsięwzięcia.

T. Würtenberger, Die Akzeptanz von Verwaltungsentscheidungen, Baden-Baden 1996, s. 82. 


\section{O potrzebie akceptacji w postępowaniu administracyjnym}

Od lat 70. ubiegłego stulecia obserwujemy stopniowe zmiany w zakresie rozumienia i funkcjonowania administracji oraz związanego z nią postępowania administracyjnego ${ }^{7}$. Obraz administracji jako tej instytucji państwowej, która podejmuje decyzje ponad obywatelem, uległ w ostatnich czasach istotnemu przeobrażeniu. Odtąd jest ona widziana jako ta część działalności państwa, którą w różnych odsłonach charakteryzują takie cechy jak przydanie jej w państwie o cechach kooperatywnych nowej roli wspomagającej, pojmowanie administracji jako służby użyteczności publicznej bądź w kategoriach New Public Management, a wreszcie postrzeganie administracji jako działalności publicznej otwartej na partycypację grup społecznych interesów. W tym ostatnim przypadku chodzi zarazem o wskazanie, jak dalece osiągnięcie celu, jakim jest akceptacja podjętych w postępowaniu administracyjnym decyzji może, a w jakim stopniu musi być (z)realizowana.

Za szczególnego rodzaju przeszkodę uchodzi kwestia kształtowania i przestrzegania terminów. Znakomita większość uregulowań prawnych w zakresie planowania w Niemczech przewiduje wyznaczenie terminu i tym samym czasu umożliwiającego wymianę poglądów oraz dyskusję. Zarazem służy on możliwie najszerszemu (po)informowaniu władz i zainteresowanych stron o stanie rzeczy, jak również wyjaśnieniu kwestii budzących wątpliwości, a wreszcie usunięciu na drodze porozumienia sprzeciwu bądź zastrzeżeń. Wspomniana uznaniowość (Ermessen) pozwala w tym kontekście prowadzącym dane postępowanie na ustalenie przedmiotowego terminu jako terminu przeprowadzenia postępowania rozjemczego ${ }^{8}$. Prowadzący takie postępowanie, zachowując się jak sędzia, ma przy tym za zadanie ustalić z wszystkimi zainteresowanymi stronami faktyczny stan w trakcie przeprowadzanego postępowania.

7 Handwörterbuch zur Verwaltungsreform, red. R. Voigt, R. Walkenhaus Wiesbaden 2006, s. XXIII-XXVII.

8 G. Gaentzsch, Der Erörterungstermin im Planfeststellungsverfahren - Instrument zur Sachverhaltsaufklärung oder Einladung zur Verfahrensverzögerung?, [w:] Verfassung - Umwelt - Wirtschaft: Festschrift für Dieter Sellner, red. K. - P. Dolde, S. Paetow, E. Schmidt-Assmann, München 2010, s. 219-236; A. Schink, Bürgerakzeptanz durch Öffentlichkeitsbeteiligung in der Planfeststellung, „Zeitschrift für Gesetzgebung” 2011, nr 3, s. 226, 239. 
Bez wątpienia akceptacja i obowiązywanie prawa są ze sobą silnie powiązane. Władztwo państwa, w dłuższej perspektywie, spełnia się bowiem najlepiej wtedy, gdy opiera się na obywatelskim posłuszeństwie wynikającym nie tyle z przymusu, ile właśnie z przekonania. Stąd państwo dla sprawności swojego funkcjonowania potrzebuje, mówiąc wprost za Dirkiem Ehlersem, współpomocy (Mithilfe) ze strony swoich obywateli ${ }^{9}$. Ma to miejsce dlatego, że prawo osiąga i zachowuje swoją ważność, jeśli jest ono pewne akceptacji większości adresatów jego norm ${ }^{10}$. Mówimy tutaj naturalnie o państwie prawa zorganizowanym na modłę demokratyczną, które - z reguły - rezygnuje z policyjnego nadzoru realizacji przyjętego przez siebie porządku prawnego. Tak rozumiana akceptacja jest tu zatem niezbędnym warunkiem psychologiczno - prawnym sprawnego funkcjonowania demokratycznego państwa prawa, o czym - w przypadku jego braku - łatwo się przekonać, gdy realizacja przykładowo wielkich projektów inwestycyjnych i/lub infrastrukturalnych napotyka na poważny opór społeczny.

Nie zaskakuje w tej sytuacji, że w tego rodzaju sytuacjach udział obywateli $\mathrm{w}$ procesie podejmowania decyzji administracyjnych jest nie tylko nośny społecznie, ale i politycznie pożądany ${ }^{11}$. Ale nie do końca. Propozycje nowych rozwiązań prawnych pozostawiają bowiem pewien deficyt, gdyż nie odwołują się one wprost do założeń demokracji partycypatywnej. Tymczasem kwestia przedmiotowej akceptacji, jej ustrojowego usytuowania w instrumentarium administracyjnym państwa jest niczym innym jak właśnie wyborem perspektywy obywatela ${ }^{12}$. I to niezależnie od tego, czy obywatelowi określona decyzja administracyjna wydaje się (prawnie, rzeczowo, ekonomicznie lub ekologicznie) prawidłowa, znośna bądź nietrafna, ale mimo to (jednak) zasługująca na przyjęcie, czy też wręcz przeciwnie: fałszywa i nie do przyjęcia. Owo spektrum oceny obywatelskiej dowodzi, że akceptacja obejmuje tu zarówno przypadki konsensu i (niekiedy także) identyfikacji, jak i jednak róż-

9 Allgemeines Verwaltungsrecht, red. D. Ehlers, H. Pünder, Berlin 2015, 1 XII 100, s. $60-61$.

10 R. Zippelius, Allgemeine Staatslehre, München 2017, § 3 II 2, \$ 9 I 2.

11 Dokumentują ten fakt w odniesieniu do Niemiec: Handbuch für eine gute Bürgerbeteiligung 2012, Leitfaden für eine neue Planungskultur 2013, bądź Verwaltungsvorschrift zur Intensivierung der Öffentlichkeitsbeteiligung in Planungs- und Zulassungsvorschrift 2014.

12 T. Würtenberger, Die Akzeptanz..., s. 61 i n. 
nic. Tym samym konieczne się staje oddzielenie w zakresie akceptacji określonej decyzji administracyjnej jej prawnej zgodności (Richtigkeit) od słuszności i możliwości przyjęcia (Vertretbarkeit) ${ }^{13}$.

\section{Akceptacja społeczna w postępowaniu administracyjnym, czyli zmiana paradygmatu}

Wzmiankowane zmiany w praktykowaniu demokracji poprzez nadanie jej cech partycypatywnych i responsywnych są nie tylko (pośrednim) dowodem zachodzących przemian w kulturze funkcjonowania administracji, ale i (bezpośrednią) wskazówką, że analizowana kwestia akceptacji odzwierciedla zasadniczą zmianę paradygmatu w prawie postępowania administracyjnego. Wszystko dlatego, że za dobro publiczne od czasu partycypatywnego uzupełnienia wzorca demokracji reprezentatywnej nie są już (więcej) odpowiedzialne tylko państwo i jego administracja ${ }^{14}$, ale również inne podmioty o charakterze lokalnym i regionalnym, a które domagają się włączenia ich w postępowanie administracyjne. Trudno bowiem zaprzeczyć, że wspieranie od dołu demokratycznej legitymacji wykonywania władzy pozwala włączyć obywateli w opracowywanie tych decyzji administracyjnych, które leżą w ich żywotnym interesie bądź też ich (bez)pośrednio dotyczą właśnie na poziomie lokalnym lub regionalnym ${ }^{15}$.

Mimo, wydawałoby się oczywistych zalet takiego sposobu rządzenia, nadal jednak pojawiają się ostrzegawcze głosy, według których idea partycypatywnych (współ)rządów jest nie do pogodzenia z zasadami demokracji reprezentatywnej tak, jak widzi ją ustrojodawca w niemieckiej Ustawie Zasadniczej ${ }^{16}$. Pogląd ten zaskakuje o tyle, o ile (jeśli pominąć przy tym rozważania w za-

13 R. Pitschas, Maßstäbe des Verwaltungshandelns, [w:] W. Hoffmann-Riem, E. Schmidt-Aßmann, A. Vosskuhle, Grundlagen des Verwaltungsrechts, München 2012, t. II, $\$ 42$ Rdnr $212 \mathrm{n}$.

14 T. Würtenberger, Zeitgeist und Recht, Tübingen 1991, s. 110.

15 R. Zippelius, T. Würtenberger, Deutsches Staatsrecht, München 2008, § 10 Rdnr 6, 10; U. Schliesky, Souveränität und Legitimität von Herrschaftsgewalt, Tübingen 2004, s. 173.

16 Tu przykładowo z nowszej literatury fachowej: H.-G. Dederer, Korporative Staatsgewalt, Tübingen 2004, s. 200; E.-W. Böckenförde, Demokratische Willensbildung und Repräsentation, [w:] Handbuch des Staatsrechts der Bundesrepublik Deutschland, red. 
kresie wykładni monizmu prawa) wziąć pod uwagę przykłady zaczerpnięte $\mathrm{z}$ funkcjonowania Unii Europejskiej. I tak w art. 11 ust. 1 TUE czytamy, że „Za pomocą odpowiednich środków instytucje umożliwiają obywatelom i stowarzyszeniom przedstawicielskim wypowiadanie się i publiczną wymianę poglądów we wszystkich dziedzinach działania Unii”, natomiast w art. 11 ust. 2 TUE znajdujemy, że „Instytucje [UE] utrzymują otwarty, przejrzysty i regularny dialog ze stowarzyszeniami przedstawicielskimi i społeczeństwem obywatelskim". Nawet jeśli uwzględnić, że mowa tu o poziomie unijnym, a nie narodowym, to i tak nie zmienia to w niczym wymowy faktu, że przywołane uregulowania traktatowe są dobrą wskazówką potrzeby włączania form partycypatywnych we współczesne praktykowanie demokracji.

Za oczywistą uchodzić powinna zatem teza, u której podstaw leży przekonanie, że porządek prawny wynikający z zasady demokratycznego państwa prawa musi odpowiadać politycznym życzeniom i wyznawanym przez społeczeństwo wartościom także na poziomie lokalnym bądź regionalnym ${ }^{17}$. Jeśli wobec tego administracja na przedmiotowym poziomie jest wyposażona w instrumentarium umożliwiające konkretyzację określonego (spodziewanego) porządku prawnego, to musi ona zmierzyć się z rzeczonymi oczekiwaniami społecznymi po to, aby potencjalne konflikty rozwiązać w sposób możliwy do zaakceptowania. Tymczasem przywołane przykłady zaleceń prawnych o charakterze podręcznikowym dowodnie pokazują, że u podstaw żadnego $\mathrm{z}$ nich nie leży bynajmniej zasada demokracji partycypatywnej lub responsywnej. Jedyne co tam znajdujemy, to zaledwie nawoływanie do „komunikatywnego pośrednictwa politycznego w formie stałego dialogu”, który miałby tak oto prowadzić do kooperacji między administracją, zainteresowanymi stronami a opinią publiczną ${ }^{18}$.

$\mathrm{Na}$ takim sposobie myślenia ciąży niewątpliwie w dalszym ciągu etatystyczne przekonanie o odpowiedzialności państwa i jego administracji za dobro publiczne. I pominięcie strony społecznej, czego tu już dodawać (zapewne) nie musimy. Tymczasem według wykładni partycypatywnej

J. Isensee, P. Kirchhof, Heidelberg 2005, t. III, $\$ 34$, Rdnr 7; M. Kaltenborn, Streitvermeidung und Streitbeilegung im Verwaltungsrecht, Baden-Baden 2007, s. 130.

17 B. Becker, Öffentliche Verwaltung, Starnberg 1989, s. 514-529.

18 A. Benz, Kooperative Verwaltung: Funktionen, Voraussetzungen und Folgen, Baden-Baden 1994, s. 307 i n. 
ustroju demokratycznego rolą administracji jest organizowanie procesu decyzyjnego, który prowadzi(łby) do zgodnego rozwiązania konfliktu zamiast podejmowania przez nią decyzji autonomicznie ${ }^{19}$. Ta, tak pożądana społecznie elastyczność w działaniu administracyjnym jest szczególnie dobrze widoczna i potrzebna zarazem, gdy dochodzi do finalnych rozstrzygnięć administracyjnych w zakresie planowania przestrzennego bądź wszędzie tam, gdzie stopień uznaniowości leżącej po stronie administracji pozwala na istotne odstępstwa $\mathrm{w}$ realizacji przyjętych lub oczekiwanych decyzji ${ }^{20}$.

\section{Mediacja jako (pożądany) element konstrukcyjny akceptacji}

Osiągnięcie stanu akceptacji (społecznej) decyzji administracyjnych powinno stanowić cel nie tylko samego postępowania administracyjnego, ale również postępowania mediacyjnego ${ }^{21}$. Stąd, już od końca lat 90. ubiegłego stulecia coraz częściej stawiano w niemieckiej literaturze fachowej pytanie o możliwość prywatyzacji postępowania administracyjnego. Inaczej mówiąc, o wprowadzenie bądź dopuszczenie do udziału w takim postępowaniu mediatora spoza administracji. Użyty czas przeszły jest tu o tyle zasadny, o ile uwzględnić, że w międzyczasie do porządku prawnego w Niemczech wprowadzono instytucję mediatora jako „osoby niezależnej i neutralnej bez kompetencji decyzyjnych” (ust. 2), natomiast samą mediację wykłada się tam jako „poufne i ustrukturyzowane postępowanie, $\mathrm{w}$ którym strony zmierzają $\mathrm{z}$ pomocą jednego bądź wielu mediatorów dobrowolnie i na własną odpowiedzialność do osiągnięcia polubownego załatwienia sporu" (ust. 1) 22 .

19 T. Würtenberger, Rechtliche Optimierungsgebote oder Rahmensetzungen für das Verwaltungshandeln?, „VVDStRL” 1999, nr 58, s. 139, 166 i n.

20 M. Wickel, $\$ 74 \mathrm{VwVfG}$, [w:] Verwaltungsrecht. Handkommentar, red. M. Fehling, B. Kastner, R. Störmer, Baden-Baden 2016, \$74 VwVfG, Rdnr 120 n.

21 S. Ferz, Mediation im öffentlichen Bereich. Eine rechtstatsächliche und rechtsdogmatische Studie für Österreich und Deutschland, Wien 2013, s. 320-344.

22 Art. $1 \$ 1$ Gesetz zur Förderung der Mediation und anderer Verfahren der außergerichtlichen Konfliktbeilegung vom 21. Juli 2012, BGBl. I, 2012, nr 35, s. 1577. Por. także uwagi na ten temat u: J. Malte von Bargen, Mediation im Verwaltungsverfahren nach Inkrafttreten des Mediationsförderungsgesetzes; „ZUR” 2012, nr 9, s. 468-474. 
Zwrócenie uwagi na brak kompetencji decyzyjnych mediatora wynika z faktu, że - nadal - kompetencja taka jest implikacją przyjęcia zasady działania władzy wykonawczej w oparciu o ustawy (Gesetzesvorbehalt). Stąd, konsekwentnie, kompetencja ta przysługuje wobec tego administracji jako jej zadanie. I nie może zatem zaskakiwać, że to właśnie administracja podejmuje na własną odpowiedzialność odpowiednią procedurę wykonawczą $\mathrm{w}$ celu podjęcia decyzji zgodnie $\mathrm{z}$ wymogami ustawowymi ${ }^{23}$. Aby przy tym w swoich decyzjach władza wykonawcza nie była prekludowana za pośrednictwem wyników postępowania mediacyjnego, to ostatnie postępowanie musi być - jak chce tego Federalny Sąd Administracyjny (Bundesverwaltungsgericht) w swoim orzeczeniu z 3 marca 2011 r. (BVerwGE 139, 150) - oddzielone od postępowania administracyjnego w sposób nie budzący wątpliwości. Wcielenie osiągniętego z pomocą mediatora kompromisu (ugody) między stronami $\mathrm{w}$ wiążące prawnie postanowienie pozostaje zatem $\mathrm{z}$ reguły zadaniem właściwych władz.

W praktyce przychodzi niezwykle trudno odpowiednim władzom pominąć wynik zakończonego sukcesem postępowania mediacyjnego. Takie działanie zostałoby bowiem bez wątpienia odebrane po stronie zainteresowanych jako podważanie sensu postępowania mediacyjnego ${ }^{24}$. Można przy tym z prawdopodobieństwem graniczącym z pewnością założyć, że brak uwzględnienia w sposób satysfakcjonujący przez władze w swojej decyzji tak wynegocjowanego porozumienia prowadzi(łby) do eskalacji protestu obywatelskiego.

Aczkolwiek mediacja nie została dotąd uregulowana w niemieckiej Ustawie o postępowaniu administracyjnym, to znajdujemy tam dwa rozwiązania, które ją umożliwiają.

Stosownie do nakazu efektywności prowadzenia postępowania administracyjnego pomieszczonego w $\$ 10$ zdanie $2 \mathrm{VwVfG}$ (einfach, zweckmäßig und zügig), prowadzące określoną sprawę władze mają możliwość zasugerowania stronom postępowanie o charakterze rozjemczym, gdyż zgodnie ze zdaniem $1 \S 10 \mathrm{VwVfG}$ „postępowanie administracyjne nie jest związane określonymi formami, o ile nie wymagają tego przepisy szczególne”.

23 M. Fehling, $₫ \$ 63-71$ VwVfG; S. Eisenmenger, $₫ \S 71 \mathrm{a}-71 \mathrm{e}$ VwVfG; M. Wickel, $\$ \$ 72-78$ VwVfG, [w:] Verwaltungsrecht. Handkommentar, red. M. Fehling, B. Kastner, R. Störmer, Baden-Baden 2016, § $\$ 63-78$ VwVfG.

24 J. Malte von Bargen, op.cit., s. 469, 472. 
Mając natomiast na uwadze paletę różnych możliwości mediacyjnych, władze oddziałują na wnioskodawcę stosownie do $\$ 25$ ust. 3 VwVfG (Die Behörde wirkt darauf hin) tak, aby ten możliwie najwcześniej (po)informował opinię publiczną o swoim planowanym przedsięwzięciu (frühe Öffentlichkeitsbeteiligung). Przy czym, i w jednym, i w drugim przypadku dopuszczalne jest także według $\$ 71 \mathrm{e} V \mathrm{wVfG}$ przeprowadzenie postępowania $\mathrm{w}$ formie elektronicznej ${ }^{25}$.

Można zatem stwierdzić, że akceptacja w postępowaniu administracyjnym i polubowne rozwiązanie sporu w postępowaniu mediacyjnym są równouprawnionymi strategiami działania w rozwiązywaniu sporów. Oczywistą musi się tutaj jednakże przedstawić konstatacja, że nie wszystkie rodzaje postępowania administracyjnego nadają się do zastosowania mediacji i nie wszystkie formy mediacji w przedmiotowych postępowaniach prowadzą do oczekiwanego lub pożądanego skutku. W takich obszarach wskazana jest zatem akceptacja, która nie zmierza jedynie w stronę konsensusu, ale zakłada przyjęcie również określonej decyzji administracyjnej. Ten rodzaj postępowania administracji pozostaje bez wątpienia mniej wymagający, aniżeli postępowanie mediacyjne. Stąd wartością (dodaną) w przypadku mediacji jest to, iż dzięki niej może mieć miejsce osiągnięcie porozumienia ułatwiającego akceptację realizacji danej decyzji administracyjnej. Wszędzie bowiem tam, gdzie z uwagi na możliwość oceny o charakterze uznaniowym (Ermessen) jego obszary są znaczne, tam wszędzie otwiera się pole do mediacji ${ }^{26}$.

\section{Uwagi końcowe, czyli o wartości akceptacji w procesie administracyjnej implementacji wyników postępowania mediacyjnego}

W odbiorze społecznym akceptacja określonej decyzji administracyjnej pozostaje bezsprzecznie punktem newralgicznym administracyjnej uznaniowości. Przykłady rozlicznych prób realizowania (zwłaszcza wielkich) projektów

25 H. Schmitz, $\$ 71$ e VwVfG, [w:] P. Stelkens, H. J. Bonk, M. Sachs, Verwaltungsverfahrensgesetz, München 2014.

26 T. Siegel, Mediation in Planungsverfahren, [w:] Mediation als Methode und Instrument der Konfliktmittlung im öffentlichen Sektor, red. J. Hyun Seok, J. Ziekow, Berlin 2010, s. 283, 296. 
infrastrukturalnych pokazują bowiem dowodnie, że pomijanie tzw. czynnika społecznego nigdy tym przedsięwzięciom nie wychodziło na dobre. I że brak wreszcie odwołania się do chociażby najprostszego instrumentu w tej dziedzinie, jakim są konsultacje, obnaża - w gruncie rzeczy - słabość demokratycznego państwa prawa. Nie sposób jednak zarazem nie podnieść, że ta prosta skądinąd w procesie administracyjnym implikacja decyzyjna okazuje się być bardziej złożonej natury. Jeśli bowiem uwzględnić przypadek podjęcia określonej decyzji, która pozostaje wprawdzie w zgodzie z przepisami, ale której realizacja $\mathrm{z}$ uwagi na pro publico bono jest nie do zaakceptowania po stronie społecznej, to trudno tutaj mówić o sukcesie postępowania administracyjnego.

Przyjęcie zatem założenia, że obywatel ma prawo oponować (rezonować?), ale decyzja należy - ostatecznie - do administracji, nie może tu zostać uznane za poprawne. Nigdy bowiem dość powtarzania (i pisania), że państwo $\mathrm{w}$ dostojnej łacinie Cycerona Quid enim civitas nisi iuris societas civium ${ }^{27}$, to nie tylko związek oparty na prawie. Jeśli bowiem przystać na współczesne twierdzenie, że państwo jest organizacją horyzontalną, to obowiązuje w niej ustrojowa zasada równowagi wymiennej: rezygnuję z części mojej wolności wobec ciebie, abyś ty mógł zrezygnować z części swojej wolności wobec mnie w imię wspólnej korzyści, wspólnego dobra, jakim jest dla nas pokój społeczny. Ten ostatni bowiem jest wypadkową poszanowania nie tylko woli sprawczej nadawcy (czyli administracji), ale również interesów jej adresata (czyli obywatela) ${ }^{28}$.

Szczególnie w przypadku postępowania administracyjnego, nie może zatem zabraknąć i tego komentarza, że dla nieostrych uregulowań prawnych możliwość swobody w ich interpretacji lub konkretyzacji powinna jednak znać umiar. Inaczej może to prowadzić do tego, że władza wykonawcza określałaby sama warunki dla swojego działania ${ }^{29}$. To tymczasem, jak nawoływał już „stary" Hans Kelsen ${ }^{30}$, jest nie do pogodzenia z praktykowaniem demokratycznego państwie prawa. Stąd przeciw uznaniowości zakłada się w takim właśnie typie państwa środki jak analizowaną tutaj akceptację i mediację, gdyż zmie-

\footnotetext{
27 Cycero, De republica, I. 49.

28 R. Pitschas, Die Rechtswirkungen der Mediation im Bewirkungsspektrum kollaborativer Governance, [w:] Mediation als Methode und Instrument..., s. 199, 209.

29 H. Maurer, Allgemeines Verwaltungsrecht, München 2011, § 19 I, s. 487-498.

30 H. Kelsen, Vom Wesen und Wert der Demokratie, Tübingen 1929, s. 38-46.
} 
rzają one w kierunku „maksymalizacji kontroli” sposobu rządzenia ${ }^{31}$. I zarazem poświadczają, bynajmniej nie górnolotnie, że sens przedstawicielskiej

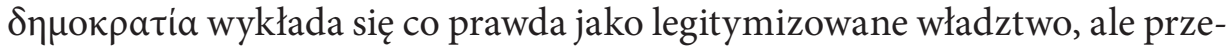
cież przy założeniu respektowaniu interesu jednostek bądź grup społecznych.

\section{Literatura}

Allgemeines Verwaltungsrecht, red. D. Ehlers, H. Pünder, Berlin 2015.

Appel I., Frühe Bürgerbeteiligung und Vorhabenakzeptanz, [w:] Verfassungsstaatlichkeit im Wandel. Festschrift für Thomas Würtenberger, red. D. Heckmann, R. P. Schenke, G. Sydow, Berlin 2013.

Becker B., Öffentliche Verwaltung, Starnberg 1989.

Benz A., Kooperative Verwaltung: Funktionen, Voraussetzungen und Folgen, Baden-Baden 1994.

Böckenförde E.-W., Demokratische Willensbildung und Repräsentation, [w:] Handbuch des Staatsrechts der Bundesrepublik Deutschland, red. J. Isensee, P. Kirchhof, Heidelberg 2005.

Cycero, De republica, I. 49.

Dederer H.-G., Korporative Staatsgewalt, Tübingen 2004.

Ferz S., Mediation im öffentlichen Bereich. Eine rechtstatsächliche und rechtsdogmatische Studie für Österreich und Deutschland, Wien 2013.

Franßen E., 50 Jahre Verwaltungsgerichtsbarkeit in der Bundesrepublik Deutschland, „DVBl.” 1998, nr 9.

Gaentzsch G., Der Erörterungstermin im Planfeststellungsverfahren - Instrument zur Sachverhaltsaufklärung oder Einladung zur Verfahrensverzögerung?, [w:] Verfassung - Umwelt - Wirtschaft: Festschrift für Dieter Sellner, red. K. - P. Dolde, S. Paetow, E. Schmidt-Assmann, München 2010.

Handbuch für eine gute Bürgerbeteiligung 2012, Leitfaden für eine neue Planungskultur 2013 Handwörterbuch zur Verwaltungsreform, red. R. Voigt, R. Walkenhaus Wiesbaden 2006. Huber P. M., Konsensvereinbarungen und Gesetzgebung, „Zeitschrift für Gesetzgebung“, 2002, nr 3.

Kaltenborn M., Streitvermeidung und Streitbeilegung im Verwaltungsrecht, Baden-Baden 2007.

Kelsen H., Vom Wesen und Wert der Demokratie, Tübingen 1929.

31 E. Franßen, 50 Jahre Verwaltungsgerichtsbarkeit in der Bundesrepublik Deutschland, „DVBl.” 1998, nr 9, s. 417. 
Malte von Bargen J., Mediation im Verwaltungsverfahren nach Inkrafttreten des Mediationsförderungsgesetzes; „ZUR” 2012, nr 9.

Maurer H., Allgemeines Verwaltungsrecht, München 2011.

Pache E., Tatbestandliche Abwägung und Beurteilungsspielraum. Zur Einheitlichkeit administrativer Entscheidungsfreiräume und zu deren Konsequenzen im verwaltungsgerichtlichen Verfahren - Versuch einer Modernisierung, Tübingen 2001.

Pitschas R., Die Rechtswirkungen der Mediation im Bewirkungsspektrum kollaborativer Governance, [w:] Mediation als Methode und Instrument der Konfliktmittlung im öffentlichen Sektor, red. J. Hyun Seok, J. Ziekow, Berlin 2010.

Pitschas R., Maßstäbe des Verwaltungshandelns, [w:] W. Hoffmann-Riem, E. Schmidt-Aßmann, A. Vosskuhle, Grundlagen des Verwaltungsrechts, München 2012.

Schink A., Bürgerakzeptanz durch Öffentlichkeitsbeteiligung in der Planfeststellung, ,Zeitschrift für Gesetzgebung" 2011, nr 3.

Schliesky U., Souveränität und Legitimität von Herrschaftsgewalt, Tübingen 2004.

Schmitz H., $₫ 71 \mathrm{e}$ VwVfG, [w:] P. Stelkens, H. J. Bonk, M. Sachs, Verwaltungsverfahrensgesetz, München 2014.

Siegel T., Mediation in Planungsverfahren, [w:] Mediation als Methode und Instrument der Konfliktmittlung im öffentlichen Sektor, red. J. Hyun Seok, J. Ziekow, Berlin 2010.

Verwaltungsrecht. Handkommentar, red. M. Fehling, B. Kastner, R. Störmer, Baden-Baden 2016.

Verwaltungsvorschrift zur Intensivierung der Öffentlichkeitsbeteiligung in Planungs - und Zulassungsvorschrift 2014.

Wickel M., $\$ 74$ VwVfG, [w:] Verwaltungsrecht. Handkommentar, red. M. Fehling, B. Kastner, R. Störmer, Baden-Baden 2016.

Würtenberger T., Die Akzeptanz von Verwaltungsentscheidungen, Baden-Baden 1996.

Würtenberger T., Rechtliche Optimierungsgebote oder Rahmensetzungen für das Verwaltungshandeln?, „VVDStRL” 1999, nr 58.

Würtenberger T., Zeitgeist und Recht, Tübingen 1991.

Zippelius R., Allgemeine Staatslehre, München 2017.

Zippelius R., Würtenberger T., Deutsches Staatsrecht, München 2008. 